\title{
Adult colorectal intussusception
}

\section{Christine Azzopardi, Edith Vassallo, Reuben Grech, Adrian Mizzi}

Medical Imaging, Mater Dei Hospital, Msida, Malta

\section{Correspondence to} Dr Christine Azzopardi, chrissyazz@yahoo.com

Accepted 3 June 2014

\section{DESCRIPTION}

\section{Case report}

A 30-year-old woman presented with severe lower, colicky abdominal pain and difficulty in passing flatus. Clinical examination revealed suprapubic tenderness.

An abdominal CT was performed which revealed a soft-tissue mass in the pelvis demonstrating 'a target sign' appearance confirming the diagnosis of intussusception (figure 1). The effect of the intussusceptum within the intussuscipiens creates a layered appearance. There is loss of gas within the rectum, instead, this is replaced by a soft-tissue mass of fat density (Hounsfield units -10) (figure 2). A diagnosis of rectosigmoid intussusception was carried out based on the CT findings with a presumptive diagnosis of an intramural lipoma as the primary lead point. Surgical reduction was performed with resection of the distal sigmoid colon. Histology confirmed an intramural lipoma of the sigmoid colon.

\section{DISCUSSION}

A rare cause of abdominal pain in adults is intussusception. Telescoping of bowel causes symptoms of bowel obstruction and in infants typically presents with 'blackcurrent jelly' stools. Intussusception occurs more frequently in the paediatric age group, with $5 \%$ of cases occurring in adults. In children, no underlying cause is generally found, while in adults $90 \%$ will be caused by an underlying pathology.

CT has been reported to be the most valuable tool for the diagnosis of intussusception, proving to be superior to ultrasound and contrast studies. ${ }^{2}$ In adults, intussusception is usually treated by surgical intervention. This is because of the high probability of an underlying structural lead point which may be malignant in nature. ${ }^{3}$

\section{Learning points}

- Radiological investigation is paramount in confirming the diagnosis.

- Keep in mind rare conditions which may present as abdominal pain.

- Intussusception in adults is more often associated with an underlying lead point.

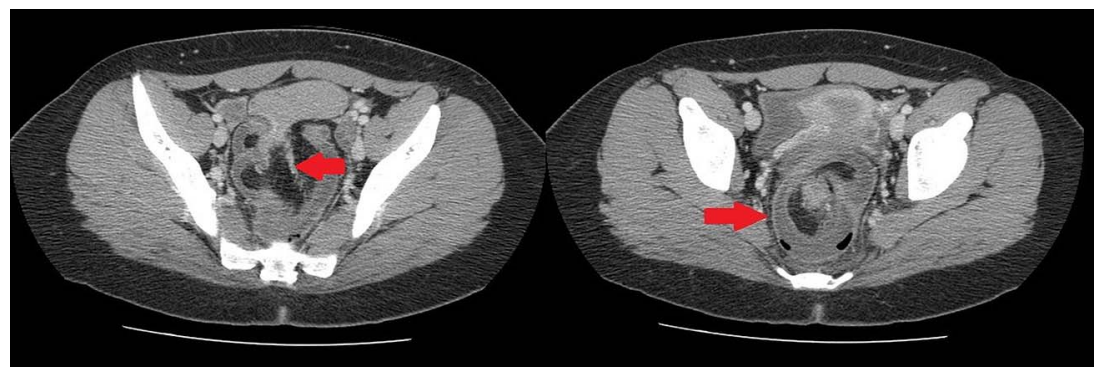

Figure 1 Axial images of a contrast-enhanced CT scan of the pelvis. On the left the mesentery is seen to twist as bowel begins to telescope through another loop of bowel (red arrow). On the right the typical 'target sign' appearance of intussusception may be appreciated (red arrow).

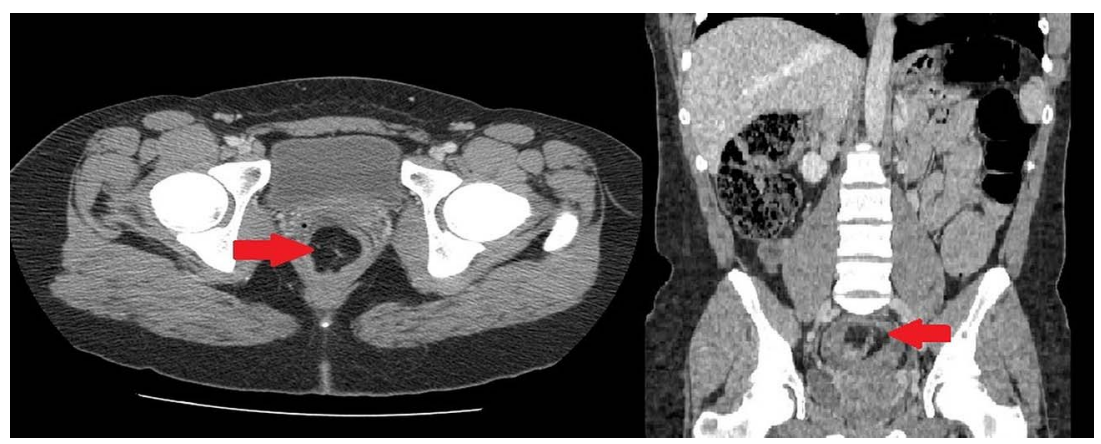

Figure 2 On the left: axial slice of a contrast-enhanced CT scan through the pelvis demonstrating soft tissue of fat density (intramural lipoma) within the rectum which proved to be the lead point for the intussusception (red arrow). On the right: coronal reconstruction demonstrating the layered appearance of bowel within bowel (red arrow). 
Contributors CA and EV performed the literature review and drafted the article. RG and AM performed the radiological diagnosis

of the patient.

Competing interests None.

Patient consent Obtained.

Provenance and peer review Not commissioned; externally peer reviewed.

\section{REFERENCES}

1 Marinis A. Intussusception of the bowel in adults: a review. World J Gastroenterol 2009; 15:407.

2 Yakan S. Intussusception in adults: clinical characteristics, diagnosis and operative strategies. World I Gastroenterol 2009;15:1985.

$3 \mathrm{Kim}$ YH. Adult intestinal intussusception: CT appearances and identification of a causative lead point. Radiographics 2006;26:733-44.

Copyright 2014 BMJ Publishing Group. All rights reserved. For permission to reuse any of this content visit

http://group.bmj.com/group/rights-licensing/permissions.

BMJ Case Report Fellows may re-use this article for personal use and teaching without any further permission.

Become a Fellow of BMJ Case Reports today and you can:

- Submit as many cases as you like

- Enjoy fast sympathetic peer review and rapid publication of accepted articles

- Access all the published articles

- Re-use any of the published material for personal use and teaching without further permission

For information on Institutional Fellowships contact consortiasales@bmjgroup.com

Visit casereports.bmj.com for more articles like this and to become a Fellow 